\title{
Growth hormone stimulates osteoprotegerin expression and secretion in human osteoblast-like cells
}

\author{
E Mrak $^{1}$, I Villa ${ }^{1}$, R Lanzi ${ }^{2}$, M Losa ${ }^{2}$, F Guidobono ${ }^{3}$ and A Rubinacci ${ }^{1}$ \\ ${ }^{1}$ Bone Metabolic Unit, ${ }^{2}$ Endocrine Unit, Scientific Institute San Raffaele, Via Olgettina, 60, 20132 Milano, Italy \\ ${ }^{3}$ Department of Pharmacology, Chemotherapy and Medical Toxicology, University of Milan, Milan, Italy \\ (Requests for offprints should be addressed to A Rubinacci; Email: a.rubinacci@hsr.it)
}

\begin{abstract}
It is presently thought that osteoprotegerin (OPG) is a cytokine involved in the regulation of osteoblast/osteoclast crosstalk and maintenance of bone mass. Recent studies showed that GH replacement therapy in $\mathrm{GH}$-deficient patients was able to induce a significant increase of OPG in the plasma, as well as in the cortical and the trabecular bone. In order to determine whether GH could directly modulate OPG secretion, the effect of GH on human osteoblast-like cells (hOB) in primary culture was studied. After detecting the presence of the mRNA for the GH receptor (GHR) by RT-PCR, hOB were exposed to increasing concentrations of $\mathrm{GH}$, from $0 \cdot 1$ to $25 \mathrm{ng} / \mathrm{ml}$, for $24 \mathrm{~h}$. The results showed that GH exposure was able to stimulate OPG secretion in a concentration-dependent manner. In addition, the OPG mRNA levels were increased, indicating that the
\end{abstract}

hormone has a stimulatory effect on gene expression. The stimulatory effect on OPG expression and production was prevented by exposing the cells to tyrphostin AG490 $(10 \mu \mathrm{M})$, an inhibitor of Janus kinase 2, which is one of the kinases involved in the intracellular pathway activated by the binding of $\mathrm{GH}$ to its receptor. Similar results were obtained when the cells were exposed to a receptor antagonist of $\mathrm{GH}$, pegvisomant at $50 \mathrm{nM}$. GH exposure neither induced an increase in IGF-I expression nor secretion in hOB. These results suggest that the stimulation of OPG production induced by $\mathrm{GH}$ in $\mathrm{hOB}$ is specific and receptor mediated and further support the view that $\mathrm{GH}$ is able to modulate bone remodeling by directly influencing osteoblast-osteoclast crosstalk.

Journal of Endocrinology (2007) 192, 639-645

\section{Introduction}

Besides growth hormone $(\mathrm{GH})$ effect on skeletal growth, the hormone plays a regulatory role on bone remodeling through the concerted action of GH itself, insulin-like growth factors (IGFs), and IGF-binding protein (IGFBP) produced either by the liver or locally (Ohlsson et al. 1998, Ueland 2004). The $\mathrm{GH}$ regulatory role in bone remodeling and maintenance of bone mass has been clearly established in clinical studies, where patients with acquired GH deficiency in adulthood (GHD) were found to have secondary osteoporosis, characterized by reduced bone mass, increased fracture risk, and decreased bone remodeling (Holmes et al. 1994, Wuster et al. 2001). Replacement therapy in GHD patients induces a dose-dependent increase of bone remodeling, as evaluated by relevant biochemical markers that peak at 3-6 months after the start of treatment and remain elevated throughout the 2 years of observation time (Nielsen et al. 1991, Joannsson et al. 1996). Acromegalic patients, who have chronic systemic GH and IGF-I excess, are characterized by increased bone turnover and biochemical markers of bone formation and bone resorption that correlate with circulating GH and IGF-I levels, suggesting the activation of both osteoblasts and osteoclasts in modulating bone turnover (Ezzat et al. 1993).
Maor et al. (1989) showed that GH is able to directly induce bone formation in vitro. The effects of $\mathrm{GH}$ on bone cells are mediated through the functional GH receptors (GHRs). Expression of the GHR has been reported in cultured human osteoblast-like cells (hOB; Nilsson et al. 1995) and in rat osteoblast-like cell lines (Barnard et al. 1991). The receptor is a member of the cytokine/hematopoietic receptor superfamily that has no intrinsic tyrosine kinase activity (Kelly et al. 1993). Binding of GH to GHR promotes receptor dimerization and initiates a cascade of events leading to protein phosphorylation and activation of nuclear proteins and transcription factors. In osteoblasts, binding of GH to its receptor leads to the activation of a cytoplasmic tyrosine kinase, Janus kinase 2 (Jak2), that phosphorylates its own and GHR tyrosine residues (Argetsinger et al. 1993), which in turn activates several members of the STAT family of transcriptional factors (Gerland et al. 2000). As summarized by Ueland (2004), GH and IGF-I/-II may regulate osteoblast proliferation (Kassem et al. 1993, Nilsson et al. 1995), while $\mathrm{GH}$ has IGF-independent effects on differentiation. In fact, the hormone induces an increase in the markers of osteoblast differentiation, such as osteocalcin and alkaline phosphatase (Kassem et al. 1993). GH is able to stimulate osteoclastic bone resorption through direct and indirect actions on osteoclast 
differentiation and through indirect activation of mature osteoclasts, possibly through local IGF-I/-II (Nishiyama et al. 1996, Kanatani et al. 2000).

Critical for the bone resorptive process is the balance between the recently discovered member of the tumor necrosis factor (TNF) ligands and family of receptors, osteoprotegerin (OPG) and receptor activator of nuclear factor-kB ligand (RANKL) produced by osteoblasts, which are the dominant mediators of osteoclastogenesis under osteoblast control. OPG acts as an endogenous inhibitor of osteoclast differentiation and activation by binding to RANKL, and thus neutralizing and preventing its binding to the specific receptor RANK expressed on osteoclasts and their precursors (Hofbauer et al. 2000), resulting in decreased osteoclastogenesis and osteoclast function. Several hormones, growth factors, cytokines, and prostaglandins regulate the OPG/RANKL/RANK system through their direct effects on bone cells (Cheung et al. 2003, Suda et al. 2004). Even GH appears to modulate this system, since $\mathrm{GH}$ replacement therapy enhances OPG levels both in blood (Lanzi et al. 2003) and in trabecular and cortical bone explants from GHdeficient patients (Ueland et al. 2002). Since the production of $\mathrm{OPG}$ is required for the maintenance of bone mass and $\mathrm{GH}$ has anabolic effects on the bone, the aim of the present study was to investigate whether $\mathrm{GH}$ could modulate OPG expression and production in hOB. On the basis of the results obtained, it was evaluated whether $\mathrm{GH}$ effects on hOB were direct or mediated by the locally produced IGF-I.

\section{Materials and Methods}

\section{Cell culture}

Bone cells were established in culture by a modification of the Gehron Robey \& Termine (1985) procedure from trabecular bone samples obtained from waste material from orthopedic surgery for degenerative diseases or traumatic fractures of the femoral neck requiring osteotomy procedures. Donors gave their informed consent for the use of the waste material. None of the patients (51-73 years old) submitted to surgery had any malignant or metabolic bone diseases other than senile osteoporosis and osteoarthritis. Briefly, the trabecular bone was cut into small pieces $(2 \times 2 \times 2 \mathrm{~mm})$ and washed thoroughly with commercial standardized Joklik's modified MEM serum-free medium (Sigma) to remove nonadherent marrow cells. The bone pieces were incubated with the same medium containing $0.5 \mathrm{mg} / \mathrm{ml}$ collagenase (type IV; Sigma) at $37^{\circ} \mathrm{C}$ for $30 \mathrm{~min}$, with rotation. The collagenase digestion was stopped by adding Iscove's modified Dulbecco's medium (IMDM; Eurobio, Les Ulis, France) containing 10\% fetal bovine serum (FBS; HyClone, Logan, UT, USA). The bone pieces (8-10 from each patient) were then placed in $25 \mathrm{~cm}^{2}$ flasks and cultured in IMDM containing 10\% FBS, $100 \mathrm{U} / \mathrm{ml}$ penicillin, $100 \mu \mathrm{g} / \mathrm{ml}$ streptomycin, $50 \mathrm{U} / \mathrm{ml}$ mycostatin, and $0 \cdot 25 \mu \mathrm{g} / \mathrm{ml}$ amphotericin B. Cells began to migrate within
1-2 weeks and reached confluence after 1 month. Culture medium was changed every $2-3$ days. The cell population was tested for alkaline phosphatase and osteocalcin production after the addition of $10^{-8} \mathrm{M} 1,25(\mathrm{OH})_{2} \mathrm{D}_{3}$ to ensure that the cells were endowed with osteoblast characteristics. Alkaline phosphatase was determined in the cell layer solubilized with $0.5 \mathrm{ml}$ of $0 \cdot 1 \%$ SDS by measuring the $p$-nitrophenol phosphate reduction (Roche Diagnostics). Osteocalcin was measured by IRMA (Nichols, San Juan Capistrano, CA, USA). All cells were used at the first passage to reduce the possibility of phenotype changes.

\section{Reverse transcriptase PCR}

Total RNA was extracted from hOB using TRIzol according to the manufacturer's instructions (Invitrogen, Inc.). RNA pellets were dissolved in sterile distilled water and their concentrations were determined spectrophotometrically (optical density $(\mathrm{OD})_{260 / 280}$ ). One microgram total RNA was retrotranscribed in a total volume of $25 \mu \mathrm{l}$ using an oligodT primer $(0 \cdot 5 \mu \mathrm{M})$, $200 \mathrm{U}$ Moloney murine leukemia virus (M-MLV) reverse transcriptase, deoxynucleotides $(0.5 \mathrm{mM}), \mathrm{M}-\mathrm{MLV}$ reaction buffer $1 \times$, and rRNasin ribonuclease inhibitor $1 \mathrm{U} / \mu \mathrm{l}$ (Promega). According to the sequences published in GenBank, we constructed specific primers for the human GHR (GenBank NM000163: Forward (Fw) 5'-CCCTATATTGACAACAT CAGTTCC-3' and Reverse (Rev) $5^{\prime}$-TTTCCTTCCTT GAGGAGATCTGG-3') that amplified a $330 \mathrm{bp}$ sequence and for IGF-I (GenBank NM000618: Fw5-'AGCAGTC TTCCAACCCAATTA-3' and Rev5'-CACGGACAGAGC GAGCTG-3') that amplified 355 bp (Luo et al. 2005). PCR was performed in a final volume of $20 \mu \mathrm{l}$ containing cDNA $(4 \mu \mathrm{l}$ RT-PCR \pm solution), $1 \mu \mathrm{M}$ primers, $10 \mu \mathrm{M}$ of each deoxyNTP, Taq polymerase $(0.5 \mathrm{U})$, and PCR buffer $1 \times$ supplied with $\mathrm{MgCl}_{2}$ (2 $\mathrm{mM}$; Promega). The PCR was performed with a thermal cycler (Tpersonal, Whatman Biometra, Goettingen, Germany) using the following conditions: (a) for GHR: an initial denaturation at $94{ }^{\circ} \mathrm{C}$ for $5 \mathrm{~min}$, followed by $30 \mathrm{PCR}$ cycles of denaturation at $94^{\circ} \mathrm{C}$ for $45 \mathrm{~s}$, annealing at $55^{\circ} \mathrm{C}$ for $90 \mathrm{~s}$, and polymerization at $72{ }^{\circ} \mathrm{C}$ for $90 \mathrm{~s}$; (b) for IGF-I: an initial denaturation at $94{ }^{\circ} \mathrm{C}$ for $5 \mathrm{~min}$ followed by 25,28 , and $34 \mathrm{PCR}$ cycles of denaturation at $94^{\circ} \mathrm{C}$ for $45 \mathrm{~s}$, annealing at $48^{\circ} \mathrm{C}$ for $45 \mathrm{~s}$, polymerization at $72^{\circ} \mathrm{C}$ for $60 \mathrm{~s}$, and then a final extension of $10 \mathrm{~min}$ at $72^{\circ} \mathrm{C}$. The products of PCR were finally analyzed on a $2 \%$ tris acetate EDTA (TAE) agarose gel. The DNA ladder used was PCR Low Ladder Set (100 bp ladder; Sigma). IGF-I expression was compared with the expression of the housekeeping gene glyceraldehyde-3phosphate dehydrogenase $(G A P D H)$ used as an internal control.

\section{Real-time PCR}

OPG and IGF-I mRNA relative expressions were evaluated by real-time PCR in hOB obtained from four and three different donors respectively. For OPG mRNA determination, after $48-\mathrm{h}$ serum-free medium incubation, $\mathrm{hOB}$ at 
confluence were treated with $5 \mathrm{ng} / \mathrm{ml}$ human $\mathrm{GH}$ for 4,6 , and $24 \mathrm{~h}$, or with both pegvisomant $(50 \mathrm{nM})$ or tyrphostin AG490 $(10 \mu \mathrm{M})$ alone, or in association with $\mathrm{GH}$ for $24 \mathrm{~h}$. For IGF-I mRNA determination, after 48-h serum-free medium incubation, hOB at confluence were treated with $5 \mathrm{ng} / \mathrm{ml} \mathrm{GH}$ for 6 and $24 \mathrm{~h}$. As previously described, total RNA was isolated with TRIzol and reverse transcribed $(1 \mu \mathrm{g}$ in $25 \mu \mathrm{l}$ reaction buffer) using M-MLV reverse transcriptase and oligo- $(\mathrm{dT})_{16}$ priming according to the manufacturer's protocol (Promega). Relative quantification of OPG and IGF-I gene expression were performed on an ABI PRISM 7700 sequence detector (Perkin-Elmer, Norwalk, CT, USA) using $10 \mathrm{ng}$ cDNA of the RT-PCR solution in a final volume of $25 \mu \mathrm{l}$. Primers for OPG and IGF-I amplification and minor group binding (MGB) probes (FAM dye-labeled) were provided by Assayon-demand Gene expression Assay Mix (Applied Biosystems, Foster City, CA, USA). Primers for the housekeeping gene GAPDH were used as an endogenous control (Applied Biosystems, Foster City, CA, USA). All primers were chosen to either span exon junction or lie in different exons to prevent amplification of genomic DNA. Real-time PCR was run according to the following protocol: an initial step of $2 \mathrm{~min}$ at $50{ }^{\circ} \mathrm{C}$ and $10 \mathrm{~min}$ at $95^{\circ} \mathrm{C}$ followed by 40 cycles of $15 \mathrm{~s}$ at $95^{\circ} \mathrm{C}$ and $1 \mathrm{~min}$ at $60^{\circ} \mathrm{C}$. mRNA levels were quantified using the comparative threshold-cycle $\left(C_{\mathrm{T}}\right)$ method. The amount of target mRNA in each sample was normalized to the amount of the GAPDH mRNA, designated as a calibrator, to give $\Delta C_{\mathrm{T}}$ $\left(C_{\text {Ttarget }}-C_{\text {TGAPDH }}\right)$. The amounts of target mRNA in the samples were expressed using the formula: amount of target mRNA $=2^{-\Delta \Delta \mathrm{CT}}$, where $\Delta \Delta C_{\mathrm{T}}=\Delta C_{\mathrm{T}(\text { sample 1) }}-$

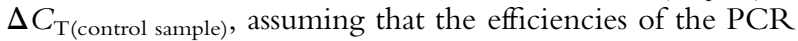
were close to 1 . Cells from different donors were analyzed in triplicate for each experimental point.

\section{Assays}

Primary cultures of human hOB were seeded into six-well multiwell plates and allowed to grow. At confluence, after 48-h serum-free medium incubation, the cells were treated for $24 \mathrm{~h}$ with increasing concentrations of $\mathrm{GH}$ $\left(0 \cdot 1-10 \mathrm{ng} / \mathrm{ml} ; 4.5 \times 10^{-12}-4.5 \times 10^{-10} \mathrm{M}\right)$ and/or in the presence of pegvisomant $\left(5 \times 10^{-8} \mathrm{M}\right)$ or tyrphostin AG490 $(10 \mu \mathrm{M})$. OPG production was measured in the conditioned media with a commercial kit (Immundiagnostik, Bensheim, Germany) and is expressed as femtomole $/ 10^{5}$ cells. IGF-I was measured using an ELISA kit (Biosource Europe SA, Nivelles, Belgium) and is expressed as nanogram/well.

\section{Statistical analysis}

The data were statistically analyzed using the statistical package GraphPad Prism version 4.00 for Windows (GraphPad Software, San Diego, CA, USA; www.graphpad. com). The significance of differences between groups was assessed by means of a one-way ANOVA for nonparametric values (Kruskal-Wallis test) and a multiple comparison test (Dunn's test).

\section{Results}

The expression of the receptor for $\mathrm{GH}$ in hOBs was controlled by RT-PCR. As expected (Nilsson et al. 1995), these cells constitutively express GHRs (data not shown). The incubation of hOBs for $24 \mathrm{~h}$ with increasing concentrations of $\mathrm{GH}(0 \cdot 1-25 \mathrm{ng} / \mathrm{ml})$ induced a rise in OPG production, which reached a plateau at $1-10 \mathrm{ng} / \mathrm{ml} \mathrm{GH}$ (Fig. 1); the higher concentrations of $25 \mathrm{ng} / \mathrm{ml}$ were less effective, showing a bell-shape trend. The maximal effect was a twofold increase in the protein production $(P<0 \cdot 001)$. Similar effects were obtained on OPG mRNA production; $\mathrm{GH}$ at $5 \mathrm{ng} / \mathrm{ml}$ was able to induce an increase in the expression of mRNA for OPG within 4-h GH exposure, which was statistically significant $(P<0 \cdot 05)$ after $6 \mathrm{~h}$ and returned to basal levels after $24 \mathrm{~h}$ (Fig. 2). To evaluate whether or not the rise in OPG production was a specific effect of $\mathrm{GH}, \mathrm{hOB}$ were treated with an antagonist of $\mathrm{GH}$, pegvisomant $(50 \mathrm{nM})$ for $15 \mathrm{~min}$ before GH. Pegvisomant per se did not induce any effect on OPG production when compared with basal secretion (untreated cells), whereas it prevented the increase in OPG induced by $\mathrm{GH}$ (Fig. 3A). A specific involvement of GHRs in OPG secretion by hOB was confirmed by pretreating the cells with an inhibitor of one of the kinases (Jak2) involved in the intracellular pathway activated by GH, tyrphostin AG490 (Tyr). Tyr treatment $(10 \mu \mathrm{M}, 15 \mathrm{~min}$ before $\mathrm{GH})$ inhibited GH-induced OPG secretion, whereas the inhibitor per se did not change OPG secretion when compared with untreated cells (Fig. 3B). The real-time PCR results showed that

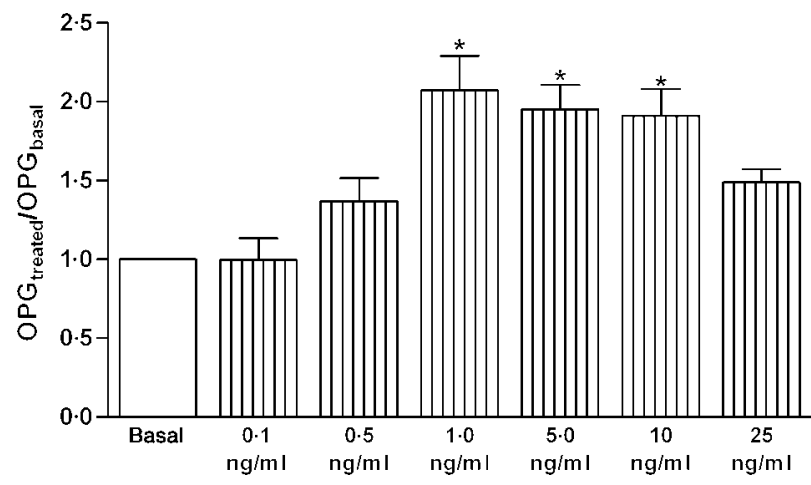

Figure 1 Concentration-dependent increase in osteoprotegerin (OPG) secretion in human osteoblast-like cells after 24-h exposure to $\mathrm{GH}$ concentrations ranging from $0 \cdot 1$ to $25 \mathrm{ng} / \mathrm{ml}(4 \cdot 5 \times$ $10^{-12}-4.5 \times 10^{-10} \mathrm{M}$ ). Data are means \pm S.E.M. of six experiments, using cells from six different donors. Basal represents OPG secretion from untreated cells. The results are expressed as the ratio of the OPG (femtomole/ $10^{5}$ cells) produced by treated and untreated cells. ${ }^{*} P<0 \cdot 001$ versus basal (Kruskal-Wallis test for nonparametric data and Dunn's multiple comparison test). 


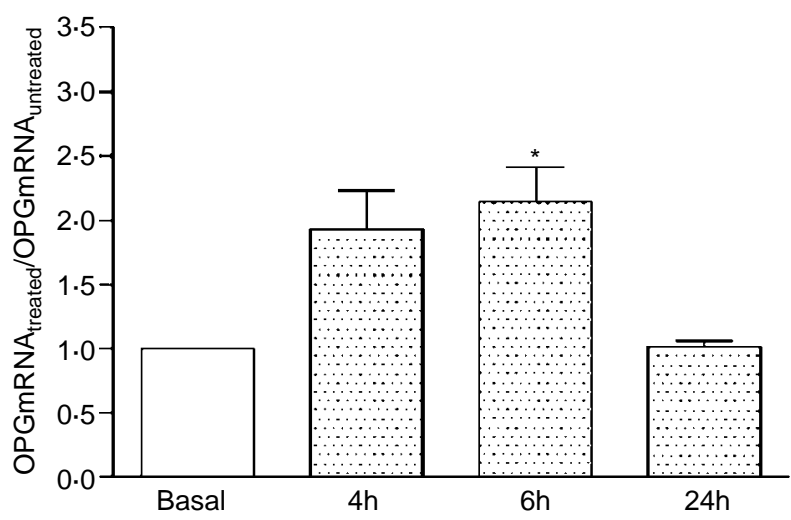

Figure 2 Real-time PCR showing the effect of $\mathrm{GH}(5 \mathrm{ng} / \mathrm{ml})$ on OPG mRNA expression in hOB after 4-, 6-, and 24-h incubation. Basal represents OPG mRNA expression in untreated cells. The results were normalized to GAPDH and the mRNA in the samples from treated cells are expressed as a ratio of the amount measured in the samples from untreated cells (see Materials and Methods for details). The results are the mean \pm S.E.M. of four experiments performed in triplicate using cells from four different donors. ${ }^{*} P<0.05$ versus basal (Kruskal-Wallis test for nonparametric data and Dunn's multiple comparison test).

pretreatment of hOB with Tyr also prevented the $\mathrm{GH}-$ induced rise of OPG mRNA (Fig. 4). Twenty-four hours of GH exposure $(5 \mathrm{ng} / \mathrm{ml})$ did not induce any significant change in IGF-I secretion (untreated cells: $1.07 \pm 0.54 \mathrm{ng} / \mathrm{well}$; treated cells: $0.63 \pm 0.08 \mathrm{ng} /$ well). In addition, the expression of mRNA for IGF-I after 6- and 24-h GH (5 ng/ml) exposure did not significantly change as shown by semiquantitative-PCR analysis (Fig. 5A) and real-time PCR (Fig. 5B). IGF-I mRNA was poorly detectable even after 34 amplification cycles (Fig. 5A).

\section{Discussion}

This study shows that $\mathrm{GH}$ is able to upregulate OPG secretion and expression by acting directly on osteoblast-like cells. These data are in line with previous in vivo studies demonstrating that serum OPG levels, as well as cortical and trabecular bone OPG contents, increase following GH replacement therapy in patients with GHD (Ueland et al. 2002, Lanzi et al. 2003). The fact that hOB express GHRs and that a specific GHR antagonist is able to prevent the increase in OPG secretion indicate that the effect of GH is specific and receptor mediated. This is also supported by the fact that inhibition of the activity of Jak-2, which is one of the first events that follow binding of $\mathrm{GH}$ to its receptor (Gerland et al. 2000), inhibits OPG upregulation by GH.

The response of hOB to GH exposure appears to be direct, not mediated by IGF-I, as GH did not increase IGF-I expression or secretion in these cells. Unlike hOB, in osteogenic sarcoma cells (SaOS-2) and murine osteoblasts,
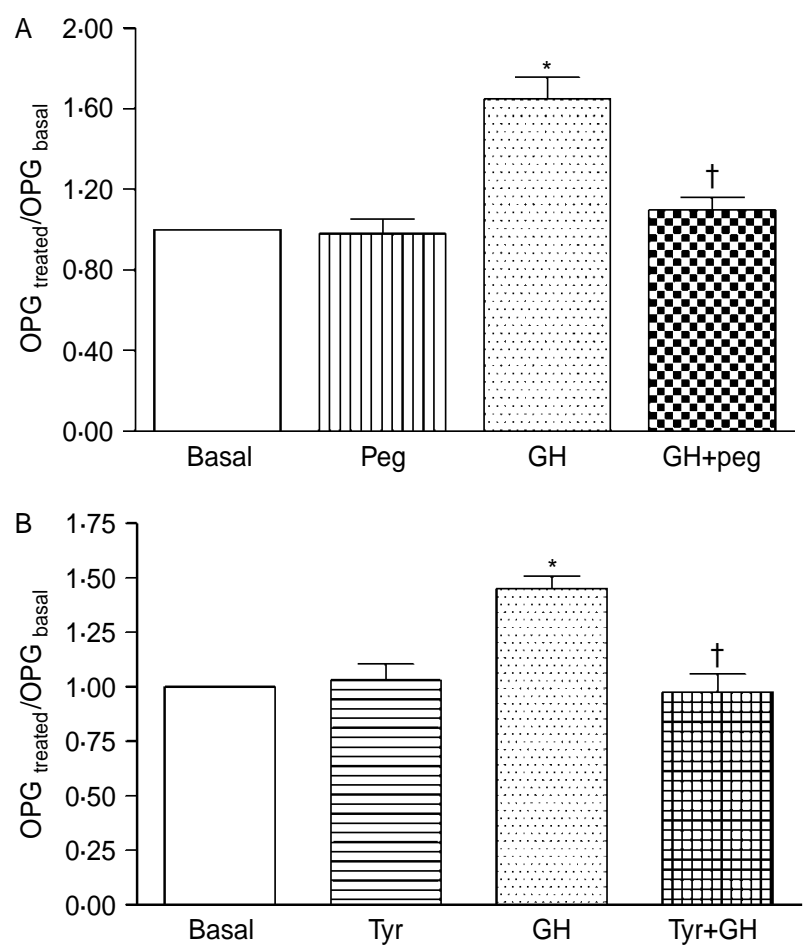

Figure 3 (A) Effect of the $\mathrm{GH}$ antagonist pegvisomant (Reg; $5 \times$ $10^{-8} \mathrm{M}, 15 \mathrm{~min}$ before $\mathrm{GH}$ ) on $\mathrm{GH}(5 \mathrm{ng} / \mathrm{ml})$ stimulation of osteoprotegerin (OPG) secretion measured $24 \mathrm{~h}$ after $\mathrm{GH}$ exposure in human osteoblast-like cells (hOB). The results are expressed as the ratio of the OPG (femtomole $/ 10^{5}$ cells) produced by treated and untreated cells; basal represents the OPG production $(26 \cdot 83 \pm$ $4.52 \mathrm{fmol} / 10^{5}$ cells) of untreated cells. Data are the mean \pm s.E.M. of four experiments using cells from different donors. (B) Effect of pretreatment with tyrphostin AG490 (Tyr; $10 \mu \mathrm{M})$, an inhibitor of JAK2, on OPG secretion measured $24 \mathrm{~h}$ after $\mathrm{GH}$ exposure $(5 \mathrm{ng} / \mathrm{ml})$ in hOB. The results are expressed as the ratio of the OPG (femtomole $/ 10^{5}$ cells) produced by treated and untreated cells; basal represents the OPG production $\left(26 \cdot 83 \pm 4 \cdot 52 \mathrm{fmol} / 10^{5}\right.$ cells $)$ of untreated cells. Data are the mean \pm S.E.M. of four experiments using cells from different donors. ${ }^{*} P<0 \cdot 01$ versus basal; ${ }^{\dagger} P<0 \cdot 01$ versus GH (Kruskal-Wallis test for nonparametric data and Dunn's multiple comparison test).

GH treatment increases the secretion of IGF-I (Wong et al. 1990, Scheven et al. 1991). However, the induction of IGF-I by $\mathrm{GH}$ in hOBs has not been detected by others either (Kassem et al. 1993, Kanzaki et al. 1995), thus supporting the idea that $\mathrm{GH}$ could exert direct anabolic effects on osteoblasts. IGF-I independent effects of GH on OPG secretion by hOB are further supported by the fact that IGF-I, in the same cellular system, downregulates OPG (Rubin et al. 2002). The reason for the discrepancy between GH and IGF-I effects on OPG secretion is unclear, particularly by considering that GH raises IGF-I serum levels by inducing hepatic IGF-I synthesis. However, it should be considered that the final effect on bone cells is the balance between circulating levels of GH, IGFs, IGFBP, and locally produced IGFs and IGFBPs, acting in an autocrine and paracrine way (Ueland 2004). 


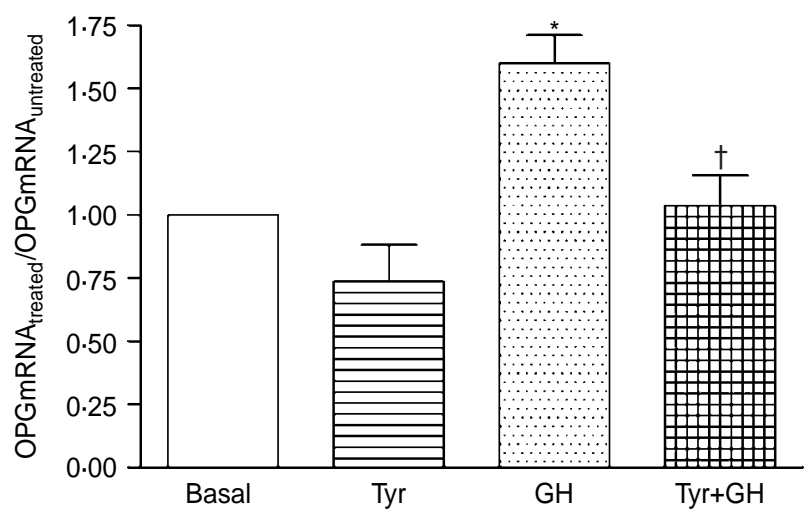

Figure 4 Real-time PCR showing the effect of tyrphostin AG490 (Tyr; $10 \mu \mathrm{M}$ ), an inhibitor of JAK2, on OPG mRNA expression in hOB after 6 - $\mathrm{h}$ incubation with $5 \mathrm{ng} / \mathrm{ml} \mathrm{GH}$. The results were normalized to GAPDH and the mRNA in the samples from treated cells are expressed as a ratio of the amount measured in the samples from untreated cells (see Materials and Methods for details). Basal represents OPG mRNA expression in untreated cells. The results are the mean \pm S.E.M. of four experiments performed in triplicate using cells from four different donors. ${ }^{*} P<0.01$ versus basal; ${ }^{\dagger} P<0.05$ versus GH (Kruskal-Wallis test for nonparametric data and Dunn's multiple comparison test).

OPG is important in maintaining bone mass, as transgenic mice without OPG develop osteoporosis (Mizuno et al. 1998), whereas mice overexpressing OPG develop osteopetrosis (Yamashita et al. 2002). The increase of OPG in hOB suggests that $\mathrm{GH}$ may set bone remodeling outcome (i.e. increased or decreased bone mass) by balancing the ratio OPG:RANKL in the microenvironment. Following GH treatment, despite the overall activation of bone turnover (Joannsson et al. 1996), the osteoclast activity may be relatively reduced by the increase of OPG with a subsequent positive shift toward bone neodeposition at each remodeling unit (Lanzi et al. 2003).

It has recently been observed that OPG, besides being a decoy receptor for RANKL, can also have a direct effect on purified osteoclasts as it modulates the expression of key proteases involved in bone resorption activity (Wittrant et al. 2002), suggesting a more complex regulation of bone resorption by this cytokine than just preventing binding of RANKL to RANK. OPG, in fact, directly inhibits the expression of cathepsin $\mathrm{K}$ and TRAP mRNA and stimulates metalloproteinases-9 (MMP-9; Wittrant et al. 2002). Tartrate resistant-acid phosphatase and cathepsin $\mathrm{K}$ are predominantly involved in the bone matrix solubilization (Garnero et al. 1998) and MMP-9 is essential for the initiation of bone resorption (Wittrant et al. 2002). The stimulatory effect on MMP-9 synthesis and expression, and the inhibition of tartrate resistant-acid phosphatase and cathepsin K by OPG are likely to stimulate further research to explain the effect of $\mathrm{GH}$ through OPG upregulation in hOB.

Understanding the mechanism involved in the regulation of osteoclast and osteoblast activities by a hormone that stimulates both terms of the remodeling equation in a mature
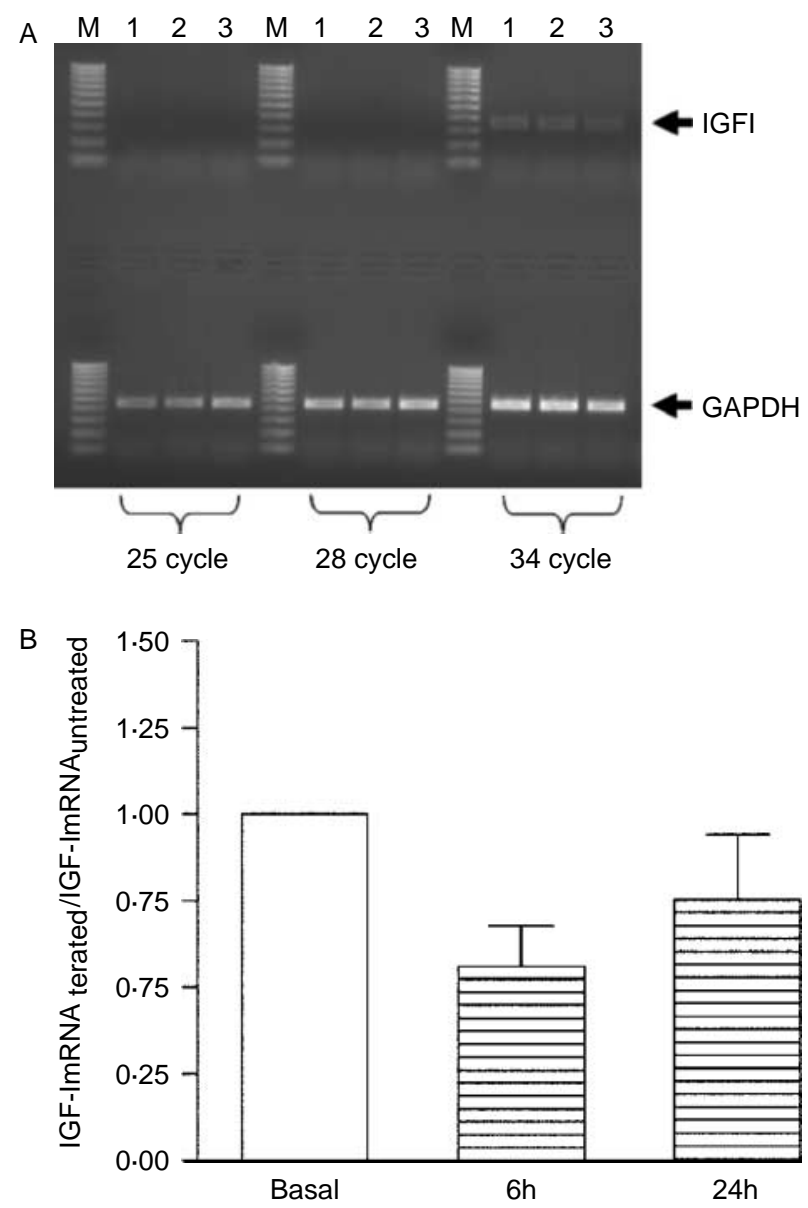

Figure 5 (A) IGF-I mRNA expression in primary cultures of human osteoblast-like cells after 6 - and 24-h exposure to $\mathrm{GH}(5 \mathrm{ng} / \mathrm{ml})$. Lane M, DNA ladder; lane 1, PCR product of untreated cells; lane 2, PCR product of cells treated with $\mathrm{GH}(5 \mathrm{ng} / \mathrm{ml})$ for $6 \mathrm{~h}$; and lane 3, PCR product of cells treated with $\mathrm{GH}(5 \mathrm{ng} / \mathrm{ml})$ for $24 \mathrm{~h}$. GAPDH expression was used as an internal reference. The reaction was stopped at different cycles of the PCR to demonstrate that the effect is not due to the plateau phase. The experiment was carried out thrice with cells from three different donors. (B) Real-time PCR showing the effect of $\mathrm{GH}(5 \mathrm{ng} / \mathrm{ml})$ on IGF-I mRNA expression in hOB after 6 - and 24-h incubation. The results were normalized to GAPDH, and the mRNA in the samples from treated cells are expressed as a ratio of the amount measured in the samples from untreated cells (see Materials and Methods for details). Basal represents IGF-I mRNA expression in untreated cells. The results are the mean \pm s.E.M. of three experiments performed in triplicate using cells from three different donors.

skeleton is essential to elucidating the physiological role on bone metabolism. In fact, in adults who lose bone because resorption cavities are incompletely repaired, an increase in bone turnover would most likely amplify the rate of bone loss (Parfitt 1991). However, this is not the case with GH, as several clinical studies have shown that $\mathrm{GH}$ administration increases bone turnover, as well as bone mass in elderly men (Rudman et al. 1990), in postmenopausal women (Landin-Wilhelmsen et al. 2003), and in GHD patients (Schlemmer et al. 1991). Such an effect requires, as 
hypothesized by Parfitt (1991), a favorable shift in the focal balance between resorption and formation during each remodeling cycle as can be produced by other hormones, such as PTH (Tashjian \& Gagel 2006).

In conclusion, this study has demonstrated that $\mathrm{GH}$ directly affects OPG synthesis and expression in hOB. The effect is specific and does not require the involvement of IGF-I. The OPG:RANKL equilibrium achieved under GH stimulus might determine a positive bone mass outcome as it relatively reduces the resorption phase of the activated bone remodeling sequence to a pro-formative activity. Based upon these results, the concern about recombinant human GH treatment of osteoporosis, raised by the editorial of Rosen \& Wüster (2003), should be reconsidered.

\section{Acknowledgements}

The authors declare that there is no conflict of interest that would prejudice the impartiality of this scientific work.

\section{References}

Argetsinger LS, Campbell GS, Yang X, Witthuhn BA, Silvennoinen O, Ihle JN \& Carter-Su C 1993 Identification of JAK2 as a growth hormone receptor-associated tyrosine kinase. Cell 74 237-244.

Barnard R, Ng KW, Martin TJ \& Waters MJ 1991 Growth hormone (GH) receptors in clonal osteoblast-like cells mediate a mitogenic response to GH. Endocrinology 128 1459-1464.

Cheung J, Mak YT, Papaioannou S, Evans BAJ, Fogelman I \& Hampson G 2003 Interleukin-6 (IL-6), IL-1, receptor activator of nuclear factor- $\kappa \mathrm{B}$ ligand (RANKL) and osteoprotegerin production by human osteoblastic cells: comparison of the effects of $17-\beta$ oestradiol and raloxifene. Journal of Endocrinology 177 423-433.

Ezzat S, Melmed S, Endres D, Eyre DR \& Singer FR 1993 Biochemical assessment of bone formation and resorption in acromegaly. Journal of Clinical Endocrinology and Metabolism 76 1452-1457.

Garnero P, Borel O, Byrjalsen I, Ferreras M, Drake FH, McQueney MS, Foged NT, Delmas PD \& Delaisse JM 1998 The collagenolytic activity of cathepsin $\mathrm{K}$ is unique among mammalian proteinases. Journal of Biological Chemistry 273 32347-32352.

Gehron Robey P \& Termine JD 1985 Human bone cells in vitro. Calcified Tissue International 37 453-460.

Gerland K, Bataillé-Simoneau N, Baslé M, Fourcin M, Gascan H \& Mercier L 2000 Activation of the Jak/Stat signal transduction pathway in GH-treated rat osteoblast-like cells in culture. Molecular and Cellular Endocrinology 168 1-9.

Hofbauer LC, Khosla S, Dunstan CR, Lacey DL, Boyle WJ \& Riggs BL 2000 The roles of osteoprotegerin and osteoprotegerin ligand in the paracrine regulation of bone resorption. Journal of Bone and Mineral Research 15 2-12.

Holmes SJ, Economou G, Whitehouse RW, Adams JE \& Shalet SM 1994 Reduced bone mineral density in patients with adult onset growth hormone deficiency. Journal of Clinical Endocrinology and Metabolism 78 669-674.

Joannsson G, Rosen T, Bosaeus I, Sjostrom L \& Bengtsson BA 1996 Two years of growth hormone $(\mathrm{GH})$ treatment increases bone mineral content and density in hypopituitary patients with adult onset GH deficiency. Journal of Clinical Endocrinology and Metabolism 81 2865-2873.

Kanatani M, Sugimoto T, Nishiyama K \& Chihara K 2000 Stimulatory effect of insulin-like growth factor binding protein-5 on mouse osteoclast formation and osteoclastic bone-resorbing activity. Journal of Bone and Mineral Research 15 902-910.
Kanzaki S, Baxter RC, Knutsen R, Baylink DJ \& Mohan S 1995 Evidence that human bone cells in culture secrete insulin-like growth factor (IGF)-II and IGF binding protein-3 but not acid-labile subunit both under basal and regulated conditions. Journal of Bone and Mineral Research 10 854-858.

Kassem M, Blum W, Ristelli J, Mosekilde L \& Eriksen EF 1993 Growth hormone stimulates proliferation and differentiation of normal human osteoblast-like cells in vitro. Calcified Tissue International 52 222-226.

Kelly PA, Ali S, Rozakis M, Goujon I, Nagano M, Pellegrini I, Gould D, Djiane J, Ederry M \& Finidori J 1993 The growth hormone/prolactin receptor family. Recent Progress in Hormone Research 48 123-164.

Landin-Wilhelmsen K, Nilsson A, Bosaeus I \& Bengtsson BA 2003 Growth hormone increases bone mineral content in postmenopausal osteoporosis: a randomized placebo-controlled trial. Journal of Bone and Mineral Research 18 393-405.

Lanzi R, Losa M, Villa I, Gatti E, Sirtori M, Dal Fiume C \& Rubinacci A $2003 \mathrm{GH}$ replacement therapy increases plasma osteoprotegerin levels in GH-deficient adults. European Journal of Endocrinology 148 185-191.

Luo SM, Tan WM, Deng WX, Zhuang SM \& Luo JW 2005 Expression of albumin IGFI, IGFBP3 in tumor tissues and adjacent non-tumor tissues of hepatocellular carcinoma patients with cirrhosis. World Journal of Gastroenterology 11 4272-4276.

Maor G, Hochberg Z, von der Mark K, Heinegard D \& Silbermann M 1989 Human growth hormone enhances chondrogenesis and osteogenesis in a tissue culture system of chondroprogenitor cells. Endocrinology 125 $1239-1245$

Mizuno A, Amizuka N, Irie K, Murakami A, Fujise N, Kanno T, Sato Y, Nakagawa N, Yasuda H, Mochizuki S et al. 1998 Severe ostoporosis in mice lacking osteoclastogenesis inhibitory factor/osteoprotegerin. Biochemical and Biophysical Research Communication 247 610-615.

Nielsen HK, Jorgensen JO, Brixen K \& Christiansen JS 1991 Serum osteocalcin and bone isoenzyme alkaline phosphatase in growth hormone deficient patients: dose-response studies with biosynthetic human $\mathrm{GH}$. Calcified Tissue International 48 82-87.

Nilsson A, Swolin D, Enerback S \& Ohlsson C 1995 Expression of functional growth hormone receptors in cultured human osteoblast-like cells. Journal of Clinical Endocrinology and Metabolism 80 3483-3488.

Nishiyama K, Sugimoto T, Kaji H, Kanatani T, Kobayashi T \& Chihara K 1996 Stimulatory effect of growth hormone on bone resorption and osteoclast formation. Endocrinology 137 35-41.

Ohlsson C, Bengtsson BA, Isaksson OGP, Andreassen TT \& Slootweg MC 1998 Growth hormone and bone. Endocrine Reviews 19 55-79.

Parfitt AM 1991 Growth hormone and adult bone remodelling. Clinical Endocrinology 35 467-470.

Rosen CJ \& Wüster C 2003 Growth hormone rising: did we quit too quickly? Journal of Bone and Mineral Research 18 406-409.

Rubin J, Ackert-Bicknell CL, Zhu L, Fan X, Murphy TC, Nanes MS, Marcus R, Holloway L, Beamer WG \& Rosen CJ 2002 IGF-I regulates osteoprotegerin (OPG) and receptor activator of nuclear factor-kappaB ligand in vitro and OPG in vivo. Journal of Clinical Endocrinology and Metabolism 87 4273-4279.

Rudman D, Feller AG, Nagraj HS, Gergans GA, Lalitha PY, Goldberg AF, Schlenker RA, Cohn L, Rudman IW, Mattson DE et al. 1990 Effects of human growth hormone in men over 60 years old. New England Journal of Medecine 323 1562-1563.

Scheven BA, Hamilton NJ, Fakkeldij TM \& Duursma SA 1991 Effects of recombinant human insulin-like growth factor I and II (IGF-I/-II) and growth hormone $(\mathrm{GH})$ on the growth of normal adult human osteoblastlike cells and human osteogenic sarcoma cells. Growth Regulation 1 160-167.

Schlemmer A, Johansen JS, Pedersen SA, Jorgensen JO, Hassager C \& Christiansen C 1991 The effect of growth hormone (GH) therapy on urinary pyridinoline cross-links in GH-deficient adults. Clinical Endocrinology 35 471-476.

Suda K, Udagawa N, Sato N, Takami M, Itoh K, Woo JT, Takahashi N \& Nagai K 2004 Suppression of osteoprotegerin expression by prostaglandin E2 is crucially involved in lipopolysaccharide-induced osteoclast formation. Journal of Immunology 172 2504-2510. 
Tashjian AH \& Gagel FR 2006 Teriparatihe [human PTH (1-34)]: 2.5 years of experience on the use and safety of the drug for the treatment of osteoporosis. Journal of Bone and Mineral Research 21 354-365.

Ueland T 2004 Bone metabolism in relation to alterations in systemic growth hormone. Growth Hormone and IGF Research 14 404-417.

Ueland T, Bollerslev J, Flybjerg A, Hansen TB, Vahl N \& Mosekilde L 2002 Effects of twelve months of $\mathrm{GH}$ treatment on cortical and trabecular bone of IGFs and OPG in adults with acquired GH deficiency: a double blind, randomized, placebo-controlled study. Journal of Clinical Endocrinology and Metabolism 87 2760-2763.

Wittrant Y, Couillaud S, Theoleyre S, Dunstan C, Heymann D \& Redini F 2002 Osteoprotegerin differentially regulates protease expression in osteoclast culture. Biochemical and Biophysical Research Communication 293 $38-44$.

Wong GL, Kotliar D, Schlaeger D \& Brandes SJ 1990 IGF-I production by mouse osteoblasts. Journal of Bone and Mineral Research 5 133-140.
Wuster C, Abs R, Bengtsson BA, Bennmarker H, Feldt-Rasmussen U, Hernberg-Stahl E, Monsom JP, Westberg B \& Wilton P 2001 The influence of growth hormone deficiency, growth hormone replacement therapy, and other aspects of hypopituitarism on fracture rate and bone mineral density. Journal of Bone and Mineral Research 16 398-405.

Yamashita T, Okada S, Higashio K, Nabeshima Y \& Noda M 2002 Double mutations in klotho and osteoprotegerin gene loci rescued osteopetrotic phenotype. Endocrinology 143 4711-4717.

Received in final form 23 November 2006 Accepted 12 December 2006 Made available online as an Accepted Preprint 27 December 2006 